\title{
TINGKAT KEBERHASILAN INSEMINASI BUATAN DOUBLE DOSIS PADA SAPI PERSILANGAN ONGOLE DENGAN KUALITAS BERAHI YANG BERBEDA
}

\author{
Alifian Ibnu Ansori1 ${ }^{\star}$, Kuswati, Asri Nurul Huda2, Rizki Prafitri3, Aulia Puspita Anugra \\ Yekti4 dan Trinil Susilawati5 \\ Fakultas Peternakan Universitas Brawijaya \\ ${ }^{*}$ Corresponding E-mail: ansorialfian@gmail.com
}

\begin{abstract}
ABSTRAK
Tujuan dari penelitian ini untuk mengetahui tingkat keberhasilan inseminasi buatan double dosis pada jam ke-8 dan jam ke-16 pada sapi Persilangan Ongole dengan kualitas berahi yang berbeda. Materi dalam penelitian ini menggunakan 25 ekor sapi betina Persilangan Ongole yang dipilih secara purposive. Metode dalam penelitian ini adalah observasi langsung di lapang, dengan menyeleksi sapi betina dengan kriteria BCS $>3$, umur $>1,5$ tahun dan telah melahirkan. Penelitian ini menggunakan semen beku pejantan Limousin yang diproduksi oleh Balai Besar Inseminasi Buatan (BBIB) Singosari, Malang. Hasil penelitian menujukkan persentase karakteristik yaitu Non Return Rate (NRR-1, NRR-2) masing-masing 92,31\% dan 58,33\%, Conception Rate (CR) 38,46\% dan 25\%, Pregnancy Rate (PR) 53,85\% dan 50\%. Suhu Vagina $37,0-37,9^{\circ} \mathrm{C}$ dan $>38,0^{\circ} \mathrm{C}$ NRR-1, NRR-2 masing-masing $77,78 \%$ dan $57,14 \%$, CR $14,28 \%$ dan $33,33 \%$, PR $42,86 \%$ dan $55,56 \%$. Lendir servik (ada, basah, sedikit) dan (ada, basah, banyak) NRR1, NRR-2 masing-masing $89,47 \%$ dan $16,67 \%$, CR $31,58 \%$ dan $16,67 \%$, PR $47,37 \%$ dan $66,67 \%$. Lendir Servik pH 7 dan pH 8 NRR-1, NRR-2 masing-masing $77,78 \%$ dan $68,75 \%$, CR $11,11 \%$ dan $37,50 \%$, PR $44,44 \%$ dan 56,25\%. Nilai HD 21-30 dan 31-40 NRR-1, NRR-2 masing-masing 50\% dan $82,35 \%$, CR $12,50 \%$ dan $35,29 \%$, PR $50 \%$ dan $52,94 \%$. Kesimpulan penelitian ini bahwa karakteristik warna vulva merah, suhu vagina $>38^{\circ} \mathrm{C}$, karakteristik lendir (ada, basah, banyak), lendir servik pH 8 dan nilai HD 31 40, memberikan persentase kebuntingan yang lebih tinggi.
\end{abstract}

Kata kunci: kualitas estrus; inseminasi buatan; non retrun rate; conception rate; pregnancy rate

\section{SUCCESS RATE OF DOUBLE DOSE ARTIFICIAL INSEMINATION IN ONGOLE CROSSBRED OF OESTRUS QUALITY}

\begin{abstract}
The research aimed to find out the double dose artificial insemination success rate at $8^{\text {th }}$ hours and $16^{\text {th }}$ hours in Ongole Crossbred cows with different qualities of oestrus. The material in this research used 25 Ongole Crossbred cows which were selected purposively. The method in this research was direct observation in the field, by selecting cows according to the criteria having BCS $>3$, having age $>1.5$ years and having given birth. This research used frozen semen of Limousin male produced by the Center for Artificial Insemination (BBIB) Singosari, Malang. The research showed the percentages of characteristics, namely Non-Return Rate (NRR1, NRR2) 92.31\% and 58.33\% respectively, Conception Rate (CR) $38.46 \%$ and 25\%, Pregnancy Rate (PR) 53.85\% and 50\%. Vaginal Temperature $37.0-37.9^{\circ} \mathrm{C}$ and $>38.0^{\circ} \mathrm{C}$ NRR1, NRR2 $77.78 \%$ and $57.14 \%$ respectively, $C R 14.28 \%$ and $33.33 \%, P R \quad 42.86 \%$ and $55.56 \%$. Cervical mucus (present, wet, slight) and (present, wet, many) NRR1, NRR2 $89.47 \%$ and $16.67 \%$ respectively, $\mathrm{CR} 31.58 \%$ and $16.67 \%$, PR $47,37 \%$ and $66.67 \%$. Cervical mucus $\mathrm{pH} 7$ and $\mathrm{pH} 8$ NRR1, NRR2 $77.78 \%$ and $68.75 \%$, respectively, CR $11.11 \%$ and $37.50 \%, P R 44.44 \%$ and $56.25 \%$, HD values 21-30 and 31-40 NRR1, NRR2 50\% and 82.35\% respectively, CR $12.50 \%$ and $35.29 \%$, PR 50\% and $52.94 \%$. The research concluded that the characteristic of red vulva color, vaginal temperature $>38^{\circ} \mathrm{C}$, mucus characteristics (present, wet, many), cervical mucus $\mathrm{pH}$ of 8 , and $\mathrm{HD}$ values 31-40, give a higher percentage of pregnancy.
\end{abstract}

Keywords: Oestrus Quality; Artificial Insemination; Non-Return Rate; Conception Rate; Pregnancy Rate. 


\section{PENDAHULUAN}

Inseminasi Buatan merupakan teknologi reproduksi yang mampu meningkatkan mutu genetik ternak, sehingga dapat menghasilkan anak dengan kualitas baik dalam waktu pendek (Susilawati, 2013). Keberhasilan IB dipengaruhi oleh beberapa faktor, yaitu: bangsa ternak, kualitas berahi, deteksi berahi, keterampilan inseminator saat mendeposisikan semen, dan ketepatan waktu saat IB (Susilawati, 2011 ). Udin, dkk. (2016) menyatakan bahwa kendala yang sering terjadi pada program IB adalah pengamatan estrus yang kurang tepat, karena terbatasnya waktu dalam pengamatan estrus oleh peternak, dan kurang cermatnya mengamati tanda-tanda estrus.

Ketepatan waktu pelaksanaan IB merupakan faktor utama yang harus diperhatikan. Pada waktu IB kondisi ternak harus dalam keadaan berahi, karena pada saat itu servik dalam kondisi terbuka (Ihsan, 2010). Udin, dkk. (2016) menambahkan bahwa waktu deteksi estrus sampai mendapatkan pelayanan IB adalah saat yang sangat kritis untuk mendapatkan angka kebuntingan yang tinggi. Angka kebuntingan yang tinggi didapatkan pada interval waktu 6-24 jam setelah estrus, kemudian akan menurun. Akan tetapi, penentuan waktu berahi dan ovulasi di lapang masih sulit untuk ditentukan. Arman dan Fattah (2017) menyatakan bahwa waktu inseminasi pada sapi antara 8-24 jam khususnya 7-18 jam sebelum ovulasi, akan memberikan angka konsepsi yang paling tinggi. Selain itu, IB yang dilakukan dengan cara single dosis dan double dosis akan memiliki nilai konsepsi yang berbeda. Hasil penelitian IB yang dilakukan secara single dosis pada sapi persilangan didapatkan nilai CR sebesar 58,10\% (Susilawati, dkk 2017). Wiranto, dkk. (2020) Hasil IB double dosis pada peranakan sapi Persilangan Limousin didapatakan nilai CR yang tinggi sebesar 74,03\%. Kemudian hasil penelitian Yekti, dkk. (2019) yang melakukan IB secara double dosis dengan waktu yang sama didapatkan nilai CR sebesar $53,13 \%$. Sedangkan hasil penelitian Wiranto, dkk. (2020) yang melakukan IB double dosis dengan selang waktu 2 jam dan 8 jam setelah menunjukkan tanda-tanda berahi mendapatkan nilai CR sebesar $58,97 \%$. Penelitian ini bertujuan untuk mengetahui tingkat keberhasilan IB double dosis jam ke 8 dan jam ke 16 pada sapi Persilangan Ongole dengan kualitas berahi yang berbeda.

\section{MATERI DAN METODE Materi}

Penelitian ini dilaksanakan pada tanggal 14 Juli 2020 sampai dengan 31 Oktober 2020 di Desa Senggreng, Kecamatan Sumberpucung, Kabupaten Malang. Materi yang digunakan dalam penelitian ini adalah sapi betina Persilangan Ongole yaitu sapi persilangan antara Peranakan Ongole dengan sapi dari berbagai bangsa berjumlah 25 ekor. Sampel dipilih secara purposive, dengan kriteria sapi betina dewasa yang memiliki BCS minimal 3, dengan umur lebih dari 1,5 tahun yang diidentifikasi berdasarkan poel gigi dan memiliki kondisi yang sehat. Semen yang digunakan untuk penelitian ini adalah semen beku pejantan Limousin yang diproduksi oleh Balai Besar Inseminasi Buatan (BBIB) Singosari, Malang.

\section{Metode}

Metode yang digunakan dalam penelitian ini adalah metode observasi langsung di lapang, dengan menyeleksi ternak betina sesuai dengan kriteria dan memiliki kualitas berahi yang baik. Metode thawing dengan menggunakan air ledeng selama 10-30 detik. Teknik IB dilakukan dengan metode deep insemination (posisi pada kornua uteri). Inseminasi dilakukan double dosis pada selang waktu berahi 8 jam dan 16 jam. Maksud dari 8 jam dan 16 jam adalah IB 
dilakukan 8 jam setelah inseminator mendapat panggilan dari peternak (bila pagi, maka sorenya di IB), sedangkan 16 jam adalah 24 jam setelah inseminator mendapat panggilan awal. Variabel Pengamatan

Variabel yang diamati untuk mengetahui kualitas berahi dan keberhasilan inseminasi buatan meliputi :

Variabel Bebas :

- Warna vulva

Pengamatan warna vulva dilakukan dengan mengamati warna labio minora yang memerah saat estrus (Rachmawati, dkk. 2018).

- Suhu vagina

Pengukuran suhu vulva dilakukan dengan memasukkan termometer digital $\left({ }^{\circ} \mathrm{C}\right)$ kedalam vagina selama tiga menit pada saat berahi dan suhu yang diperoleh rata-rata sebesar 37 $39^{\circ} \mathrm{C}$ (Rachmawati, dkk., 2018).

- Lendir servik

Pengamatan lendir dilakukan dengan melihat jumlah dan konsistensi lendir yang keluar dari vulva sebelum di IB (Irfan, dkk., 2017).

- pH lendir

Pengamatan dilakukan dengan menggunakan $\mathrm{pH}$ test paper yang dimasukkan kedalam vagina, kemudian diamati nilai pHnya.

- Ketegangan Vagina

Pengukuran dilakukan dengan menggunakan alat heat detector merek Brunstmessgerat dengan skala 1-60 $\Omega$, dengan cara memasukkan HD sedalam $20 \mathrm{~cm}$ kedalam vagina. Jika ternak dalam kondisi berahi ditandai dengan munculnya angka 30-40 $\Omega$ pada HD (Annashru, dkk., 2017).

Variabel Tergantung :

- Non Return Rate (NRR)

NRR adalah ternak betina yang tidak menujukkan tanda berahi kembali Wiranto, dkk. (2020). Persentase sapi IB yang tidak menunjukkan berahi lagi pada hari ke- 18 - 21 (NRR1) dan hari ke- 40 - 42 setelah IB (NRR2). Iswoyo dan Widyaningrum (2008) menjelaskan bahwa untuk menentukan NRR, yaitu:

$$
\% N R R=\frac{\text { Jumlah sapi yang di IB }- \text { jumlah sapi di yang IB ulang }}{\text { Jumlah sapi yang di IB }} \times 100 \%
$$

- Conception Rate (CR)

Conception Rate (CR) adalah jumlah ternak yang bunting pada IB pertama hasil pemeriksaan kebuntingan (PKB) dengan melakukan palpasi rektal dibagi jumlah sapi yang di IB, dikalikan seratus (\%) (Susilawati, 2011);(Wiranto, dkk., 2020).

$$
\% \mathrm{CR}=\frac{\text { Jumlah sapi bunting pada IB pertama }}{\text { Jumlah sapi yang di IB }} \times \frac{10}{0 \%}
$$

- Pregnancy Rate (PR)

Pregnancy Rate (PR) adalah jumlah sapi yang bunting dari jumlah sapi yang di IB (Putra, dkk., 2018). Nilai PR dapat dihitung dengan rumus (Iswoyo dan Widyaningrum 2008); (Putra, dkk, 2018).

$$
\% \mathrm{PR}=\frac{\text { Jumlah sapi yang bunting }}{\text { Jumlah sapi yang di IB }} \times 100 \%
$$


Metode analisis data

Data yang didapatkan selanjutnya ditabulasi dan diolah secara statistik menggunakan Microsoft Exel, kemudian dianalisis secara deskriptif dan dibandingkan dengan parameter tingkat keberhasilan IB double dosis dengan kualitas berahi yang berbeda pada penelitian sebelumnya.

\section{HASIL DAN PEMBAHASAN}

Karakteristik Warna Vulva Terhadap Non Return Rate-1, Non Return Rate-2, Pregnancy Rate Inseminasi Buatan Double Dosis

Non Return Rate adalah ternak betina yang tidak berahi kembali dalam kurun waktu 20-60 hari atau 60-90 hari setelah dilakukan IB, maka dianggap bunting (Susilawati, 2011 ${ }^{\mathrm{a}}$ ). Dalam penelitian ini pengamatan NRR dilakukan pada hari ke 19-22, 40-43 pasca dilakukan IB, kemudian dilakukan palpasi rektal pada hari ke 60 pasca IB. Evaluasi hasil NRR sapi Persilangan Ongole terdapat pada tabel 1.

Tabel 1. Persentase Karakteristik Warna Vulva Sebelum Inseminasi Buatan Terhadap Non Return Rate pada Sapi Persilangan Ongole Inseminasi Buatan Double Dosis

\begin{tabular}{cccccc}
\hline Karakteristik Warna Vulva & \multirow{2}{*}{$\begin{array}{c}\text { Jumlah Sampel } \\
\text { (Ekor) }\end{array}$} & $\begin{array}{c}\text { Tidak } \\
\text { Berahi }\end{array}$ & $\%$ & $\begin{array}{c}\text { Nidak } \\
\text { Berahi }\end{array}$ & $\%$ \\
\hline Merah Merata & 12 & 7 & 58,33 & 7 & 58,33 \\
Merah & 13 & 12 & 92,31 & 12 & 92,31 \\
\hline Total & 25 & & & & \\
\hline
\end{tabular}

Tabel 1 menunjukan bahwa sapi dengan kondisi vulva merah merata mengalami berahi kembali sebanyak 5 ekor dan menjadikan persentase NRR-1 dan NRR-2 paling rendah yaitu $58,33 \%$. Penilaian NRR dijelaskan oleh Rosita, dkk. (2013) bahwa nilai NRR $>50 \%$ masih dalam kategori baik. Rendahnya nilai NRR disebabkan oleh banyak hal yang dapat mempengaruhi sapi betina sebelum di IB ataupun setelah di IB. Pada penelitian yang dilakukan terdapat 2 ekor sapi yang mengalami endometritis yang diketahui pada saat diperiksa menggunakan USG. Endometritis merupakan peradangan (inflamasi) endometrium uterus yang disebabkan oleh infeksi bakteri (Melia, dkk., 2014). Hasil perhitungan CR dan PR terdapat pada tabel

Tabel 2. Persentase Karakteristik Warna Vulva Sebelum Inseminasi Buatan Terhadap Coception Rate dan Pregnancy Rate pada Sapi Persilangan Ongole Inseminasi Buatan Double Dosis

\begin{tabular}{cccccc}
\hline $\begin{array}{c}\text { Karakteristik Warna Vulva } \\
\text { Sebelum linseminasi Buatan }\end{array}$ & $\begin{array}{c}\text { Jumlah Sampel } \\
\text { (Ekor) }\end{array}$ & $\begin{array}{c}\text { Ternak } \\
\text { Bunting }\end{array}$ & \%CR & $\begin{array}{c}\text { Ternak } \\
\text { Bunting }\end{array}$ & $\%$ PR \\
\hline Merah Merata & 12 & 3 & 25 & 6 & 50 \\
Merah & 13 & 5 & 38,46 & 7 & 53,85 \\
\hline Total & 25 & & & & \\
\hline
\end{tabular}

Tabel 2 menujukkan bahwa nilai CR terendah pada vulva berwarna merah merata sebesar $25 \%$, sedangkan yang tertinggi terjadi pada kondisi warna vulva merah sebesar $58,58 \%$. Untuk nilai PR terendah pada warna vulva merah merata sebesar $50 \%$ dan tertinggi pada warna vulva merah 53,85\%. Ihsan dan Wahjuningsih (2011) menjelaskan bahwa nilai CR yang baik sebesar $60 \%$, hal ini dikarenakan semakin tinggi nilai CR, maka fertilitasnya semakin tinggi. Silent heat, 
deteksi berahi yang kurang tepat dan umur ternak adalah faktor yang dapat menyebabkan rendahnya nilai CR dan PR.

\section{Pengaruh Suhu Vagina Terhadap Non Return Rate-1, Non Return Rate-2, Conception Rate, Pregnancy Rate Inseminasi Buatan Double Dosis}

Pada saat ternak dalam kondisi berahi maka akan terjadi peningkatan suhu tubuh yang disebabkan oleh kondisi hormonalnya. Sakatani, et al. (2016) menyatakan bahwa selama berahi kenaikan suhu tubuh tergantung dari hormon yang disekresikan. Tingginya estrogen saat ternak berahi menyebabkan bertambahnya jumlah jaringan pada pembuluh darah sesuai dengan perkembangan saluran reproduksi dan pada saat yang bersamaan estrogen meningkatkan aliran darah ke saluran reproduksi (Feradis, 2010). Hasil dari pengaruh suhu vagina terhadap NRR terdapat pada tabel 3 .

Tabel 3. Persentase Suhu Vagina Sebelum Inseminasi Buatan Terhadap Non Return Rate pada Sapi Persilangan Ongole Inseminasi Buatan Double Dosis

\begin{tabular}{cccccc}
\hline \multirow{2}{*}{$\begin{array}{c}\text { Suhu Vagina Sebelum } \\
\text { Inseminasi Buatan (ํㅡㄹ }\end{array}$} & Jumlah Sampel (Ekor) & \multicolumn{2}{c}{ NRR-1 } & \multicolumn{3}{c}{ NRR-2 } \\
\cline { 3 - 6 } & & $\begin{array}{c}\text { Tidak } \\
\text { Berahi }\end{array}$ & $\%$ & $\begin{array}{c}\text { Tidak } \\
\text { Berahi }\end{array}$ & $\%$ \\
\hline $37,0-37,9$ & 7 & 4 & 57,14 & 4 & 57,14 \\
$>38,0$ & 18 & 14 & 77,78 & 14 & 77,78 \\
\hline Total & 25 & & & & \\
\hline
\end{tabular}

Pada suhu vagina $>38^{\circ} \mathrm{C}$ memiliki nilai NRR-1 dan NRR-2 yang tinggi, hal ini disebabkan oleh ketepatan deteksi pada fase estrus. Irfan, dkk. (2017) menyatakan bahwa pada saat berahi suhu vagina akan mengalami kenaikan yang lebih tinggi. Penelitian Indira, et al. (2014) menjelaskan bahwa suhu vagina pada sapi Bali pada fase pro estrus sebesar $37,86 \pm 1,0^{\circ} \mathrm{C}$, fase estrus $38,39 \pm 0,29^{\circ} \mathrm{C}$, fase met estrus $38,05 \pm 0,15^{\circ} \mathrm{C}$, dan pada fase di estrus $37,4 \pm 0,74^{\circ} \mathrm{C}$.

Data pada tabel 4 menujukkan bahwa pada suhu vagina $37,0-37,9^{\circ} \mathrm{C}$ memiliki nilai $\mathrm{CR}$ $14,28 \%$ dan PR $33,33 \%$, sedangkan pada suhu $>38 \stackrel{\circ}{\circ}$ memiliki nilai CR $42,86 \%$ dan nilai PR $55,56 \%$. Nilai CR yang diperoleh tertinggi pada suhu $>38 \stackrel{\circ}{\circ}$ sebesar $42,86 \%$, tetapi hasil penelitian ini lebih rendah dari penelitian Susilawati $\left(2011^{\mathrm{a}}\right)$ yang menujukkan nilai CR pada sapi PO sebesar $80 \%$. Banyak faktor yang dapat mempengaruhi tinggi rendahnya nilai $\mathrm{CR}$, salah satunya yaitu deteksi berahi. Pada saat penelitian berlangsung, deteksi berahi yang dilakukan oleh peternak cenderung kurang tepat. Hal ini dikarenakan sebagian besar peternak masih belum mengetahui kondisi berahi pada ternak yang dipelihara, tetapi beberapa peternak dengan pengalaman beternak lebih dari 10 tahun memiliki pemahaman yang sangat baik dalam mendeteksi berahi ternaknya. Susilawati (2004) menyatakan bahwa banyak tidaknya sapi yang berahi setelah IB, dapat menyebabkan tinggi rendahnya nilai $C R$. Salah satu faktor yang menyebabkan ternak mengalami berahi kembali adalah musim, pada saat penelitian dilakukan sudah berada pada musim kemarau, sehingga pada saat tersebut pakan yang diberikan cenderung berkualitas jelek. Ihsan dan Wahjuningsih (2011) menyatakan bahwa tinggi rendahnya nilai $\mathrm{CR}$ tidak terlepas dari pemberian nutrisi pada pakan setiap harinya untuk mencukupi kebutuhan ternak. 
Tabel 4. Persentase Suhu Vagina Sebelum Inseminasi Buatan Terhadap Coception Rate dan Pregnancy Rate pada Sapi Persilangan Ongole Inseminasi Buatan Double Dosis

\begin{tabular}{cccccc}
\hline $\begin{array}{c}\text { Suhu Vagina Sebelum } \\
\text { Inseminasi Buatan }\left({ }^{\circ} \mathrm{C}\right)\end{array}$ & Jumlah Sampel (Ekor) & $\begin{array}{c}\text { Ternak } \\
\text { Bunting }\end{array}$ & \%CR & $\begin{array}{c}\text { Ternak } \\
\text { Bunting }\end{array}$ & $\%$ PR \\
\hline $37,0-37,9$ & 7 & 1 & 14,28 & 3 & 42,86 \\
$>38,0$ & 18 & 6 & 33,33 & 10 & 55,56 \\
\hline Total & 25 & & & & \\
\hline
\end{tabular}

\section{Kondisi Lendir Servik Terhadap Non Return Rate-1, Non Return Rate-2, Conception Rate, Pregnancy Rate IB Double Dosis}

Pada saat keadaan ternak normal, dalam siklus estrus akan mengeluarkan leleran lendir. Akan tetapi, tidak menutup kemungkinan ternak akan mengeluarkan lendir selain dalam kondisi berahi. Lim, et al. (2014) menyatakan bahwa kondisi berahi sapi akan mengeluarkan lendir dari dalam vulva berwarna jernih, murni dan tidak berbau. Vigil, et al. (2009); Irfan, dkk. (2017) menambahkan bahwa pada fase siklus berahi dan variasi tingkat hormonal, akan mempengaruhi perubahan jumlah dan konsistensi lendir. Berikut hasil evaluasi pengamatan karakteristik lendir servik sebelum IB double dosis terdapat pada tabel 5.

Tabel 5. Persentase Kondisi Lendir Servik Sebelum IB Terhadap Non Return Rate pada Sapi Persilangan Ongole Inseminasi Buatan Double Dosis

\begin{tabular}{cccccc}
\hline \multirow{2}{*}{$\begin{array}{c}\text { Kondisi Lendir Servik } \\
\text { Sebelum Inseminasi } \\
\text { Buatan }\end{array}$} & Jumlah Sampel (Ekor) & \multicolumn{2}{c}{ NRR-1 } & \multicolumn{2}{c}{ NRR-2 } \\
\cline { 3 - 6 } & & $\begin{array}{c}\text { Tidak } \\
\text { Berahi }\end{array}$ & $\%$ & $\begin{array}{c}\text { Tidak } \\
\text { Berahi }\end{array}$ & $\%$ \\
\hline Ada, Basah, Sedikit & 19 & 17 & 89,47 & 17 & 89,47 \\
Ada, Basah, Banyak & 6 & 1 & 16,67 & 1 & 16,67 \\
\hline Total & 25 & & & & \\
\hline
\end{tabular}

Hasil penelitian pada tabel 5 menunjukkan bahwa pada sapi yang sedang berahi dengan mengeluarkan lendir (ada, basah, sedikit) menunjukkan nilai NRR-1 dan NRR-2 yang lebih tinggi sebesar 89,47\%, sedamgkan kondisi sapi berahi dengan mengeluarkan lendir (ada, basah, banyak) memiliki nilai NRR-1 dan NRR-2 sebesar 16,67\%. Terjadinya berahi kembali pada ternak dapat dipengaruhi oleh beberapa faktor antara lain faktor genetik, fisiologis, umur, bangsa dan kondisi lingkungan.

Pada saat penelitian manajemen pemeliharaan yang dilakukan oleh sebagian besar peternak masih sangat kurang baik, salah satunya adalah kebersihan kandang. Susilawati $\left(2011^{\mathrm{b}}\right)$ menjelaskan bahwa akibat adanya endoparasit dan ektoparasit dapat menyebabkan ternak stres, sehingga gejala yang sering muncul adalah tidak munculnya tanda-tanda berahi (silent heat), terjadinya kematian embrio dini atau tidak ovulasi.

Tabel 6. Persentase Kondisi Lendir Servik Sebelum Inseminasi Buatan Terhadap Conception Rate dan Pregnancy Rate pada Sapi Persilangan Ongole Inseminasi Buatan Double Dosis

\begin{tabular}{cccccc}
\hline $\begin{array}{c}\text { Kondisi Lendir Servik } \\
\text { Sebelum Inseminasi } \\
\text { Buatan }\end{array}$ & Jumlah Sampel (Ekor) & $\begin{array}{c}\text { Ternak } \\
\text { Bunting }\end{array}$ & $\%$ CR & $\begin{array}{c}\text { Ternak } \\
\text { Bunting }\end{array}$ & $\%$ PR \\
\hline Ada, Basah, Sedikit & 19 & 6 & 31,58 & 9 & 47,37 \\
Ada, Basah, Ban yak & 6 & 1 & 16,67 & 4 & 66,67 \\
\hline Total & 25 & & & & \\
\hline
\end{tabular}


Pada tabel 6 menujukkan bahwa pada kondisi lendir (ada, basah, sedikit) memiliki nilai CR $31,58 \%$ dan PR 47,37\%. Sedangkan pada kondisi lendir (ada, basah, banyak) memiliki nilai CR $16,67 \%$ dan PR $66,67 \%$. Rendahnya nilai CR dapat disebabkan oleh banyak hal, salah satunya adalah gangguan reproduksi. Gangguan dan inefisiensi reproduksi dapat mengakibatkan tertundanya pubertas, rendahnya performa estrus, periode postpartum yang panjang dan rendahnya tingkat konsepsi (Widarini, dkk., 2017).

Ukuran Folikel dan Ovarium yang tidak optimal menjadi salah satu penyebab penurunan fertilitas. Hasil dari penelitian, pada saat dilakukan pengecekan kebuntingan menggunakan USG, didapatkan 3 ternak yang memiliki ovari yang kecil. Hal ini dapat diindikasikan menjadi salah satu penyebab rendahnya tingkat konsepsi. Priyo Jr, Budiyanti dan Kusumawati (2020) menyatakan bahwa ukuran folikel dan ovarium pada sapi SimPO dan $\mathrm{PO}$ mempengaruhi $\mathrm{Cl}$ dan S/C.

\section{Pengaruh Nilai pH Lendir Servik Terhadap Non Return Rate-1, Non Return Rate-2, Conception Rate, Pregnancy Rate Inseminasi Buatan Double Dosis}

Derajat keasaman $(\mathrm{pH})$ adalah parameter penting dari lerndir servik dalam proses transfer spermatozoa ke dalam saluran reproduksi betina, hal ini dikarenakan kualitas dan daya hidup spermatozoa didalam servik dipengaruhi oleh pH di dalam servik (Tsiligianni, et al. 2011). Hasil non return rate dari nilai $\mathrm{pH}$ lendir servik terdapat pada tabel 7.

Tabel 7. Persentase Nilai pH Lendir Servik Sebelum Inseminasi BuatanTerhadap Non Return Rate pada Sapi Persilangan Ongole Inseminasi Buatan Double Dosis

\begin{tabular}{|c|c|c|c|c|c|c|}
\hline \multirow{2}{*}{$\begin{array}{l}\text { Nilai pH } \\
\text { Sebelum } \\
\text { Buatan }\end{array}$} & \multirow{2}{*}{$\begin{array}{r}\text { Lendir Servik } \\
\text { Inseminasi }\end{array}$} & \multirow[b]{2}{*}{$\begin{array}{l}\text { Jumlah Sampel } \\
\text { (Ekor) }\end{array}$} & \multicolumn{2}{|c|}{ NRR-1 } & \multicolumn{2}{|c|}{ NRR-2 } \\
\hline & & & $\begin{array}{l}\text { Tidak } \\
\text { Berahi }\end{array}$ & $\%$ & $\begin{array}{l}\text { Tidak } \\
\text { Berahi }\end{array}$ & $\%$ \\
\hline & 7 & 9 & 7 & 77,78 & 7 & 77,78 \\
\hline & 8 & 16 & 11 & 68,75 & 11 & 68,75 \\
\hline & Total & 25 & & & & \\
\hline
\end{tabular}

Data tabel 7. menujukkan bahwa pada lendir servik dengan nilai $\mathrm{pH} 7$ memiliki persentase sebesar $77,78 \%$ pada NRR-1 dan NRR-2. Sedangkan pada lendir servik dengan nilai $\mathrm{pH} 8$ memiliki persentase sebesar $68,75 \%$ pada NRR-1 dan NRR-2. Hal ini didukung dari hasil penelitian yang dilakukan oleh Rizki, dkk. (2019) bahwa dari range $\mathrm{pH}$ lendir 7,2-7,4 mendapatkan persentase kebuntingan sebesar 100\%. Akan tetapi, penilaian kebuntingan dengan pengamatan pada NRR masih belum akurat, maka dari itu perlu dilakukan palpasi rektal untuk memastikan ternak yang di IB bunting secara akurat.

Tabel 8. Persentase Nilai pH Lendir Servik Sebelum Inseminasi Buatan Terhadap Conception Rate dan Pregnancy Rate pada Sapi Persilangan Ongole Insemiansi Buatan Double Dosis.

\begin{tabular}{cccccc}
\hline $\begin{array}{c}\text { Nilai pH Lendir Servik } \\
\text { Sebelum Inseminasi } \\
\text { Buatan }\end{array}$ & $\begin{array}{c}\text { Jumlah Sampel } \\
\text { (Ekor) }\end{array}$ & $\begin{array}{c}\text { Ternak } \\
\text { Bunting }\end{array}$ & \%CR & $\begin{array}{c}\text { Ternak } \\
\text { Bunting }\end{array}$ & $\%$ PR \\
\hline 7 & 9 & 1 & 11,11 & 4 & 44,44 \\
8 & 16 & 6 & 37,50 & 9 & 56,25 \\
\hline Total & 25 & & & & \\
\hline
\end{tabular}

Pada tabel 8 menunjukkan bahwa pada kondisi lendir servik pada pH 7 memiliki nilai $\mathrm{CR}$ $11,11 \%$ dan PR 44,44\%. Sedangkan pada lendir servik pada pH 8 memiliki nilai CR $37,50 \%$ 
dan PR 56,25\%. Persentase kebuntingan tertinggi pada penelitian ini yaitu pada $\mathrm{pH} 8$, hal ini juga didikung dari hasil penelitian Rizki, dkk. (2019) yang menyatakan bahwa pada range nilai $\mathrm{pH}$ 7,8-8,0 menujukkan angka kebuntingan yang cukup tinggi sebesar $75 \%$. Hal ini dimungkinkan adanya faktor yang mempengaruhi perbedaan dan pengaruh $\mathrm{pH}$ terhadap kebuntingan. Perbedaan $\mathrm{pH}$ lendir dipengaruhi oleh faktor kondisi biofisik dan biokimia dari lendir yang dihasilkan oleh servik yang dikendalikan oleh hormon yang berperan pada siklus estrus (Prasdini, dkk., 2015). Verma, et al. (2014) menyatakan bahwa perubahan tampilan lendir servik terjadi selama estrus yaitu, transparan pada awal estrus, keruh secara bertahap pada pertengahan estrus dan bening mengkilap pada akhir estrus.

\section{Pengaruh Nilai Heat Detector Terhadap Non Return Rate-1, Non Return Rate-2, Conception Rate, Pregnancy Rate Inseminasi Buatan Double Dosis}

Salah satu indikator yang dapat mempengaruhi tinggi rendahnya nilai NRR adalah kualitas berahi. Sapi yang berahi akan terlihat dengan ciri-ciri diantaranya: vulva membengkak, suhu tubuh meningkat, labia minora memerah, berlendir (keluar mucus atau lendir yang berasal dari servik, serta jika dinaiki pejantan akan diam (Rachmawati, dkk., 2018). Heat detector adalah alat yang dapat digunakan untuk mengetahui kualitas berahi dengan skala 1-60 $\Omega$, jika angka

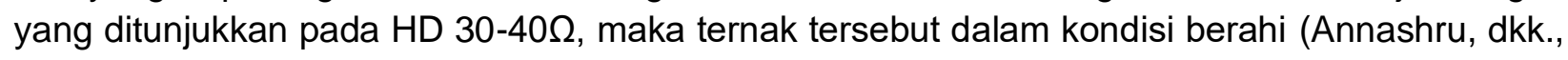
2017). Pengaruh intensitas HD terhadap NRR terdapat pada tabel 9.

Tabel 9. Persentase Nilai Heat Detector Sebelum Inseminasi Buatan Terhadap Non Return Rate pada Sapi Persilangan Ongole Inseminasi Buatan Double Dosis

\begin{tabular}{cccccc}
\hline $\begin{array}{c}\text { Nilai Heat Detector } \\
\begin{array}{c}\text { Sebelum Inseminasi } \\
\text { Buatan }\end{array}\end{array}$ & $\begin{array}{c}\text { Jumlah Sampel } \\
\text { (Ekor) }\end{array}$ & Ekor & $\%$ & Ekor & $\%$ \\
\hline $21-30$ & 8 & 4 & 50 & 4 & 50 \\
$31-40$ & 17 & 14 & 82,35 & 14 & 82,35 \\
\hline Total & 25 & & & & \\
\hline
\end{tabular}

Pada tabel 9 menujukkan bahwa pada nilai HD 21-31 memiliki nilai NRR-1 dan NRR-2 sebesar 50\%, sedangkan pada nilai HD 31-40 mendapatkan nilai NRR-1 dan NRR-2 sebesar $82,35 \%$. Hal ini menujukkan bahwa nilai HD 31-40 menandakan ternak dalam kondisi estrus yang baik. Pemayun (2014) dalam Annashru, dkk. (2017) menyatakan bahwa jika angka yang ditunjukkan jarum pada range 30-40 menandakan bahwa ternak dalam kondisi estrus, sedangkan jika angka yang ditunjukkan kurang atau lebih dari 30-40 maka ternak tersebut dalam keadaan belum atau sudah estrus.

Tabel 10. Persentase Nilai Heat Detector Sebelum IB Terhadap Coception Rate dan Pregnancy Rate pada Sapi Persilangan Ongole IB Double Dosis

\begin{tabular}{cccccc}
\hline $\begin{array}{c}\text { Nilai Heat Detector } \\
\begin{array}{c}\text { Sebelum Inseminasi } \\
\text { Buatan }\end{array}\end{array}$ & $\begin{array}{c}\text { Jumlah Sampel } \\
\text { (Ekor) }\end{array}$ & $\begin{array}{c}\text { Ternak } \\
\text { Bunting }\end{array}$ & \%CR & $\begin{array}{c}\text { Ternak } \\
\text { Bunting }\end{array}$ & $\%$ PR \\
\hline $21-30$ & 8 & 1 & 12,50 & 4 & 50 \\
$31-40$ & 17 & 6 & 35,29 & 9 & 52,94 \\
\hline Total & 25 & & & & \\
\hline
\end{tabular}

Tabel 10 menujukkan bahwa pada nilai HD 21-30 memiliki nilai CR 12,50\% dan PR 50\%, sedangkan pada nilai HD 31-40 memiliki nilai CR 35,29\% dan PR 52,94\%, dan juga menjadi 
nilai tertinggi. Akan tetapi, hasil tersebut masih dibawah hasil penelitian yang dilakukan Annasrhu, dkk. (2017) dengan hasil dari rataan nilai HD 32,29\% pada interval waktu 8-12 jam didapatkan nilai CR sebesar 37,14\%.

Salah satu faktor yang menyebabkan rendahnya kebuntingan adalah BCS. Berdasarkan hasil dari penelitian yang telah dilakukan penilaian BCS menggunakan penilaian (1 - 9) terdapat 5 ekor sapi dengan nilai BCS 3, 11 ekor sapi dengan nilai BCS 4, 8 ekor sapi dengan nilai BCS 5, dan 1 ekor mempunyai nilai BCS 6. Persentase kebuntingan pada nilai BCS 3 memiliki persentase tertinggi sebesar $80 \%$, sedangkan pada nilai BCS 4 persentase kebuntingannya sebesar $45,45 \%$, nilai BCS 5 sebesar $50 \%$, dan pada nilai BCS 6 sebesar $0 \%$ (lampiran 8). Budiawan, dkk. (2015) menyatakan bahwa BCS mempunyai hubungan dengan sistem reproduksi ternak seperti kesuburan, kebuntingan, proses kelahiran, dan laktasi, semua akan berpengaruh terhadap sistem reproduksi.

\section{KESIMPULAN}

Kesimpulan penelitian ini bahwa karakteristik warna vulva merah, suhu vagina $>38^{\circ} \mathrm{C}$, karakteristik lendir ada, basa, banyak, lendir servik dengan nilai $\mathrm{pH}$ 8, dan nilai HD 31-40, memberikan persentase kebuntingan lebih tinggi.

\section{UCAPAN TERIMA KASIH}

Terima kasih kepada Bank Indonesia Kantor Wilayah Cabang Malang sebagai penyandang dana penelitian dan Research Group Red Meat Producers yang telah mendampingi selama penelitian ini berlangsung.

\section{DAFTAR RUJUKAN}

Annashru, F. A., M. N. Ihsan, A. P. A. Yekti, T. Susilawati. 2017. Pengaruh Perbedaan Waktu Inseminasi Buatan Terhadap Keberhasilan Kebuntingan Sapi Brahman Cross. Jurnal IImu-IImu Peternakan. 27(3): 17-23.

Arman dan A. H. Fattah. 2017. Tingkat Keberhasilan Inseminasi Buatan di Desa Cenrana Kecamatan Kahu Kabupaten Bone. Jurnal Agrominansia. 2(1): 26-35.

Budiawan, A., M. N. Ihsan dan S. Wahjuningsih. 2015. Hubungan Body Condition Score Terhadap Service per Conception dan Calving Interval Sapi Potong Peranakan Ongole di Kecamatan Babat Kabupaten Lamongan. Jurnal Ternak Tropika. 16(1): 34-40.

Feradis. 2010. Reproduksi Ternak. Bandung: Alfabet.

Ihsan, M. N. 2010. IImu Reproduksi Ternak Dasar. Malang: UB Press.

Ihsan, M. N. dan S. Wahjuningsih. 2011. Penampilan Reproduksi Sapi Potong di Kabupaten Bojonegoro. Jurnal Ternak Tropika. 12(2): 76-80.

Indira, P. N., Kustono and Ismaya. 2014. The Profile of Vaginal Temperature and Cytology of Vaginal Smear in Bali Cattle During Estrus Cycle Phase. Journal of the Indonesian Tropical Animal Agriculture. 39(3): 175-179. https://doi.org/10.14710/jitaa.39.3.175-179.

Irfan, S. Wahjuningsih dan T. Susilawati. 2017. Pengaruh Lendir Servik Sebelum Inseminasi Buatan (IB) Terhadap Keberhasilan Kebuntingan Sapi Komposit. Jurnal Ternak Tropika. 18(1): 24-28.

Iswoyo dan P. Widiyaningrum. 2008. Performans Reproduksi Sapi Pernaakan Simmental (Psm) Hasil Inseminasi Buatan di Kabupaten Sukoharjo Jawa Tengah. Jurnal IImiah IImu-IImu Peternakan. 11(3): 125-133.

Lim, H. J., J. K. Son, H. B. Yoon. K. S. Baek, T. I. Kim, Y. S. Jung and E. G. Kwon. 2014. Physical Properties of Estrus Mucus in Relation to Conception Rates in Dairy Cattle. 
$\begin{array}{llll}\text { Journal of } & \text { Embryo }\end{array}$ https://dx.doi.org/10.12750/JET.2014.29.2.157.

Melia, J., Amrozi dan L. I. Tumbeleka. 2014. Dinamika Ovarium Sapi Endometritis yang Diterapi dengan Gentamicine, Flumequin dan Analog Prostaglandin F2 Alpha (PGF2 $\alpha$ ) Secara Intra Uterus. Jurnal Kedokteran Hewan. 8(2): 111-115.

Prasdani, W. A., S. Rahayu dan M. S. Djati. 2015. Level of Estrogen and Cervical Mucus pH as Indicator of Estrus After Calving Towards The Provision of Selenium-vitamin ETM on Dairy Cow Frisien Holstein (FH). International Journal of ChemTech Reserch. 7(1): 190195. https://sphinxsai.com/2015/ch vol7 no1/3/(190-195)\%20014.pdf.

Priyo Jr, T. W., A. Budiyanto dan A. Kusumawati. 2020. Pengaruh Ukuran Ovarium dan Folikel Terhadap Penampilan Reproduksi pada Sapi PO dan SimPO di Kecamatan Jatinom, Kabupaten Klaten. Jurnal Sain Veteriner. 38(1): 20-24.

Putra, W. P. B., M. Gunawan, E. M. Kalln dan S. Said. 2018. Kinerja Reproduksi Sapi Peranakan Ongole (Bos Indicus) di BPPIBT-SP Ciamis, Jawa Barat. Prosiding Seminar Teknologi dan Agribisnis Peternakan VI: Pengembangan Sumber Daya Genetik Ternak Lokal Menuju Swasembada Pangan Hewani ASUH, Fakultas Peternakan Universitas Jendral Sudirman, 7 Juli 2018: 327-334.

Rachmawati, A., Ismaya, B. P. Widyobroto, S, Bintara dan T. Susilawati. 2018. Aplikasi Inseminasi Buatan pada Induk Sapi Potong Menggunakan Semen Cair Sapi Peranakan Ongole dengan Cauda Epidydymal Plasma-2 + 0,6\% Bovine Serum Albumin. Jurnal IImu-IImu Peternakan. 28(3): 247-258.

Rizki, A., P. Srianto, E. Suprihati, T. Sardjito, Ismudiono dan M. A. A. Arif. 2019. Pengaruh pH Lendir Mukosa Vaginal Saat Birahi Terhadap Persentase Kebuntingan (Conception Rate) pada Sapi Perah di KUD Tani Wilis Kabupaten Tulungagung dan KSU Tunas Setia Baru Kabupaten Pasuruan. Ovozoa. 8(2): 154-158.

Rosita, E. A., T. Susilawati dan S. Wahyuningsih. 2014. Keberhasilan IB Menggunakan Semen Beku Hasil Sexing sengan Metode Sedimentasi Putih Telur pada Sapi PO Cross. Jurnal IImu-IImu Peternakan. 24(1): 72-76.

Sakatani, M., M. Takahashi and N. Takanouchi. 2016. The Efficiency of Vaginal Temperature Measurement for Detection of Estrus in Japanese Black Cows. Journal of Reproduction and Development. 62(2): 201-207. https://doi.org/10.1262/jrd.2015-095.

Susilawati, T. 2004. Keberhasilan IB Menggunakan Semen Sexing Setelah Dibekukan. Seminar Nasional Teknologi Peternakan dan Veteriner: 199-202.

Susilawati, T. 2011 a . Tingkat Keberhasilan Inseminasi Buatan dengan Kualitas dan Deposisi Semen yang Berbeda pada Sapi Peranakan Ongole. Jurnal Ternak Tropika. 12(2): 1524.

Susilawati, T. $2011^{\mathrm{b}}$. Spermatology. Malang: UB Press.

Susilawati, T., A. Mahfud, N. Isnaini, A. P. A. Yekti, A. N. Huda, A. T. Satria and Kuswati. 2019. The Comparison of Artificial Insemination Success Between Unsexed and Sexed Sperm in Ongole Crossbred Cattle. IOP Conference Series Earth and Environmental Science. 387: 1-3. https://doi.org/10.1088/1755-1315/387.

Susilawati, T., A.P.A. Yekti dan Kuswati. 2019. Klaster Sapi Potong. Malang : UB Press.

Tsiligianni, T., G. S. Amiridis, E. Dovolou. L. Menegatos, S. Chadio, D. Rizos and A. GutierrezAdan. 2011. Association Between Physical Properties of Cervical Mucus and Ovulation Rate in Superovulated Cows. The Canadian Journal of Veterinary Research. 75: 248253. https://www.ncbi.nlm.gov/pubmed/22468021. 
Udin, Z., F. Rahim, Hendri dan Y. Yelita. 2016. Waktu dan Kemerahan Vulva Saat Inseminasi Buatan Merupakan Faktor Penentu Angka Kebuntingan Sapi di Sumatera Barat. Jurnal Veteriner. 17(4): 501-509.

Verma, K. K., S. Prasad, A. Kumaresan, T. K. Mohanty, S. S. Layek, T. K. Patbandha and S. Chand. 2014. Characterization of Physio Chemical Properties of Cervical Mucus in Relation to Party and Conception Rate in Murrah Buffaloes. Veterinary World. 7(7): 467471. https://www.veterinaryworld.org/Vol.7/July-2014/5.pdf.

Widarini, W., I. R. Beda dan A. D. Wijayanti. Efektivitas Terapi Multivitamin, Obat Cacing dan Premix pada Sapi Terdiagnosa Hipofungsi Ovarium di Wilayah Kecamatan Prambanan, Yogyakarta. Jurnal Sain Veteriner. 35(2): 230-235.

Wiranto, Kuswati, R. Prafitri, A. N. Huda, A. P. A. Yekti dan T. Susilawati. 2020. Tingkat Keberhasilan Inseminasi Buatan Menggunakan Semen Beku Sexing pada Bangsa yang Berbeda. Jurnal Agripet. 20(1): 17-21.

Yekti, A. P. A., T. Susilawati, M. N. Ihsan dan S. Wahjuningsih. 2017. Fisiologi Reproduksi Ternak. Malang: UB Press.

Yekti, A. P. A., E. A. Octaviani, Kuswati dan T. Susilawati. 2019. Peningkatan Conception Rate dengan Inseminasi Buatan Menggunakan Semen Sexing Double Dosis pada Sapi Persilangan Ongole. Jurnal Ternak Tropika. 20(2): 135-140. 